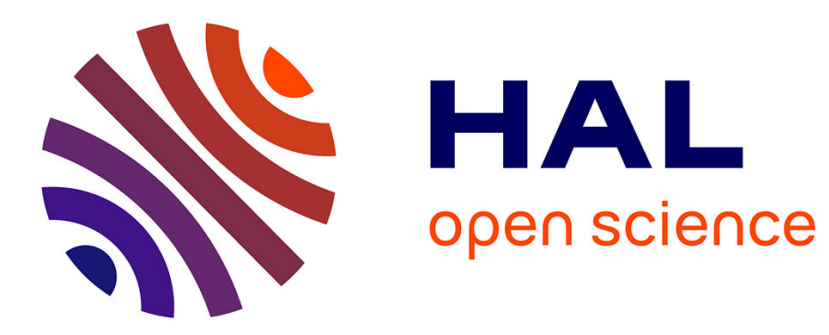

\title{
Control strategies of DC-bus voltage in islanded operation of microgrid
}

Bo Dong, Yongdong Li, Zhixue Zheng

\section{To cite this version:}

Bo Dong, Yongdong Li, Zhixue Zheng. Control strategies of DC-bus voltage in islanded operation of microgrid. 2011 4th International Conference on Electric Utility Deregulation and Restructuring and Power Technologies (DRPT), Jul 2011, Weihai, China. pp.1671-1674, 10.1109/DRPT.2011.5994166 . hal-02496101

\section{HAL Id: hal-02496101 \\ https://hal.univ-lorraine.fr/hal-02496101}

Submitted on 7 Apr 2021

HAL is a multi-disciplinary open access archive for the deposit and dissemination of scientific research documents, whether they are published or not. The documents may come from teaching and research institutions in France or abroad, or from public or private research centers.
L'archive ouverte pluridisciplinaire HAL, est destinée au dépôt et à la diffusion de documents scientifiques de niveau recherche, publiés ou non, émanant des établissements d'enseignement et de recherche français ou étrangers, des laboratoires publics ou privés. 


\section{Control Strategies of DC-Bus Voltage in Islanded Operation of Microgrid}

\author{
Bo Dong \\ Department of Electrical \\ Engineering \\ Tsinghua University \\ Beijing, China \\ dongb07@mails.tsinghua.edu.cn
}

\author{
Yongdong Li \\ Department of Electrical \\ Engineering \\ Tsinghua University \\ Beijing, China \\ liyd@mail.tsinghua.edu.cn
}

\author{
Zhixue Zheng \\ Department of Electrical \\ Engineering \\ Tsinghua University \\ Beijing, China \\ zheng-zx09@mails.tsinghua.edu.cn
}

Abstract-This paper focuses on the energy management system and stability of DC bus in both grid-connected and islanded operations in microgrid system. The microgrid system consists of wind turbines, photovoltaic panels, batteries and supercapacitors, also includes both AC and DC zones. Voltage of DC bus must be kept stable especially in islanded operation. In gridconnected operation voltage of DC bus is controlled by inverter. Real power from renewable energy generations and storage system can be transferred to AC zone through DC bus. In islanded operation, inverter must be controlled to keep magnitude and frequency of AC bus stable, so storage system is used to regulate voltage of DC bus. Simulation results in the paper show that voltage of DC bus can be kept steady and power can be kept balance with the strategy in microgrid system.

Keywords-microgrid; grid-connected operation; islanded operation; storage system

\section{INTRODUCTION (HEADING 1)}

More and more renewable energy generations such as wind turbines and photovoltaic panels are integrated into grid, which will lead grid instability because their fluctuate power.

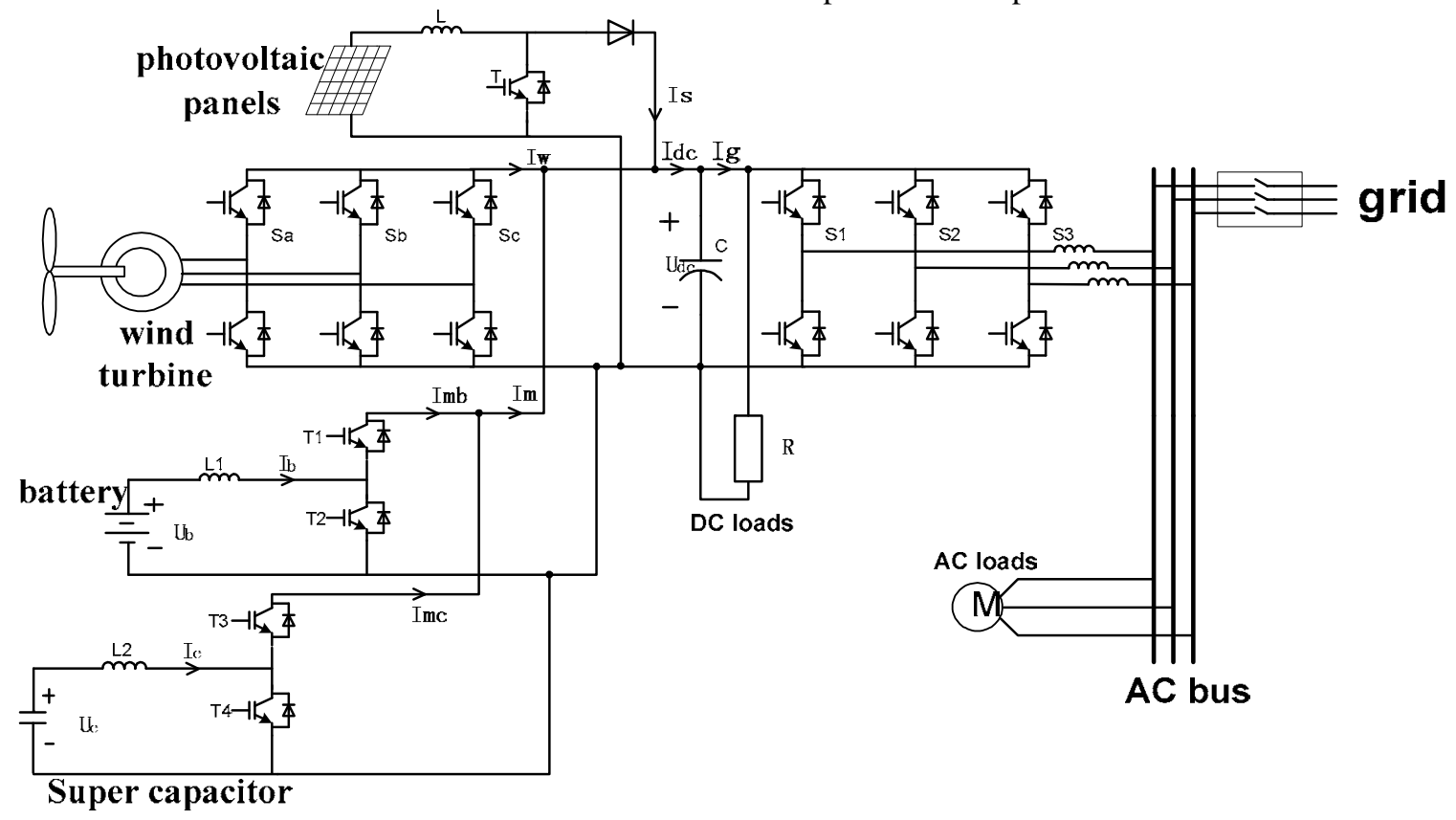

Microgrid is one of the solutions. The advantages of the microgrid consist of

- the association of the local generators and local loads in order to minimize the energy losses in the electricity transport;

- the possibility of electricity and heat cogeneration in order to increase the energy generation efficiency;

- the ease of using communication means in order to optimize the total electricity generation and to increase the quality and the reliability of the power system ${ }^{[1,2]}$.

One unit of the microgrid is established in the lab as shown in Fig 1. It consists of a wind turbine (2KW), photovoltaic panels $(1 \mathrm{KW})$, batteries (one cell is $12 \mathrm{~V}, 65 \mathrm{AH}$ and six cells series connected) and super-capacitor (72V, 70F). The stability of DC- and AC-bus voltage is very important. When microgrid is connected to the utility grid, the voltage of DC-bus voltage $(200 \mathrm{~V})$ is regulated by the inverter. However when the microgrid works in islanded operation, DC-bus voltage must be regulated by renewable energy generations and storage system. And the magnitude and frequency of AC bus are controlled by droop character of parallel inverters ${ }^{[3-5]}$. 


\section{CONTROL STRATEGY OF DC BUS}

\section{A. In Grid-Connected Operation}

Voltage of DC bus can be controlled by inverter in gridconnected operation. Control strategy of inverter is shown in Fig. 2. Real power from photovoltaic panels, wind turbine and storage system is all delivered to DC load and AC bus through DC bus when voltage of DC bus is stable. If the power is not enough for the loads, microgrid will absorb power from utility grid. If power from microgrid is more than needed, it will transfer power to utility grid.

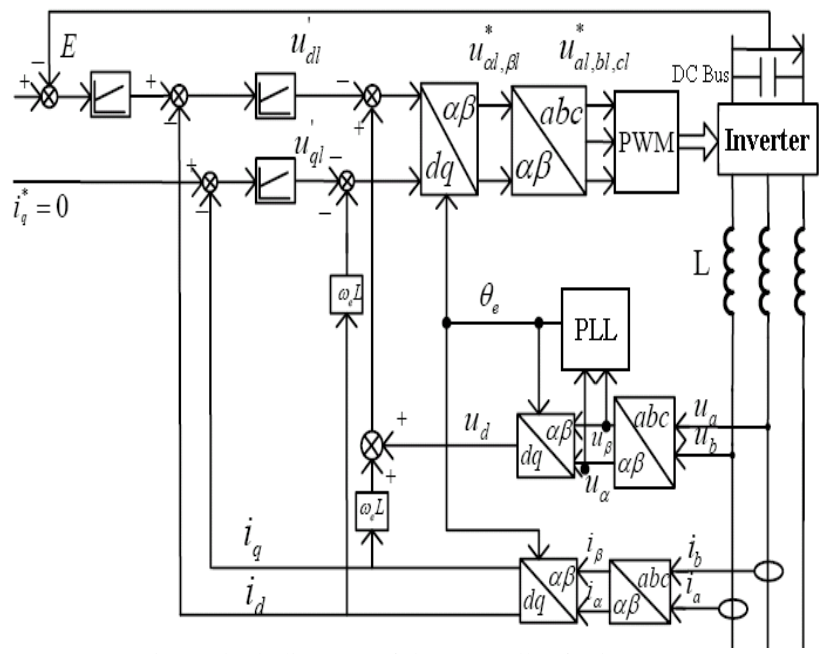

Fig 2.Block diagram of the controller for inverter

\section{B. In Islanded Operation}

Inverter must supply real and reactive power to AC zone in order to keep magnitude and frequency of AC bus stable in islanded operation when there some faults happened in utility grid. So voltage of DC bus must be regulated by Bi-DC/DC converters which connect batteries and super-capacitor to DC bus. Also because power from wind turbine and photovoltaic panels is fluctuant, storage system must absorb or release the power difference between renewable energy generations and loads which can be calculated by equation (1).

$$
P_{\text {storage }}=P_{\text {batt }}+P_{\text {sc }}=P_{\text {wind }}+P_{\text {solar }}-P_{\text {load }}
$$

where $P_{\text {storage }}$ is the total power of storage system including batteries and super-capacitor. $P_{b a t t}$ and $P_{s c}$ are power released from battery and super-capacitor respectively. And $P_{\text {wind }}$ is generated by wind turbine. $P_{\text {solar }}$ is generated by photovoltaic panels. $P_{\text {load }}$ is power absorbed by DC and AC loads.

Power flow in the microgrid system is shown in Fig. 3. Very little power is absorbed or released by DC bus. When voltage of DC bus is stable and power absorbed by DC bus is zero in a whole period and real power from renewable energy generations and storage system is all delivered to inverter through DC bus.

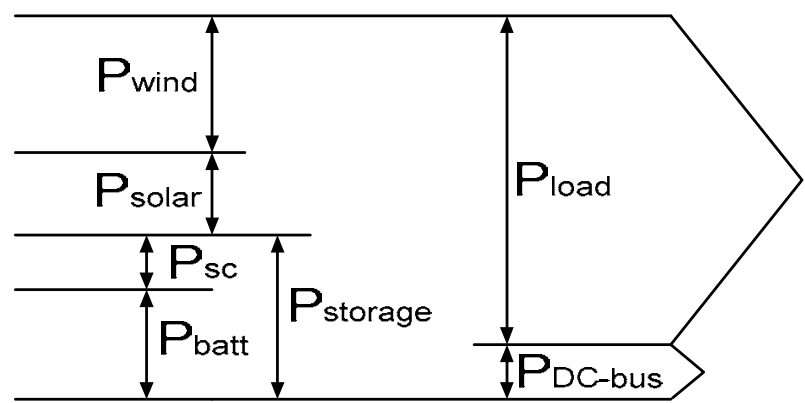

Fig 3.Power flow in the system

Power difference includes high frequency and low frequency power. Super-capacitor as a fast-dynamic storage unit is used to absorb high frequency power, and battery as a long-term storage unit is controlled to absorb low frequency power for a long time. We can get power reference with the control strategy as shown in Fig. 4 where $K$ is a gain determined by rating and state of charge of super-capacitor and batteries $^{[8]}$.

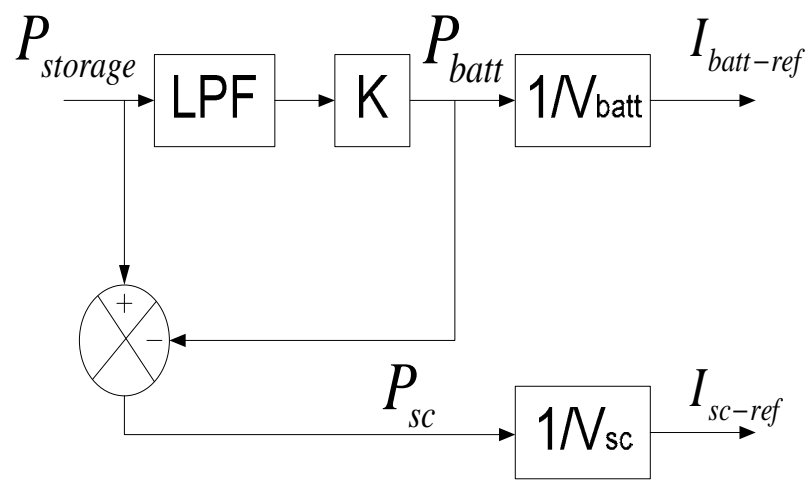

Fig 4.Control strategy of storage system

Bi-DC/DC converter is a bidirectional buck-boost converter as shown in Fig. 5. We should control PWM of T1 and T2 to make voltage of DC bus stable and absorb the power calculated by control strategy in Fig. 4.

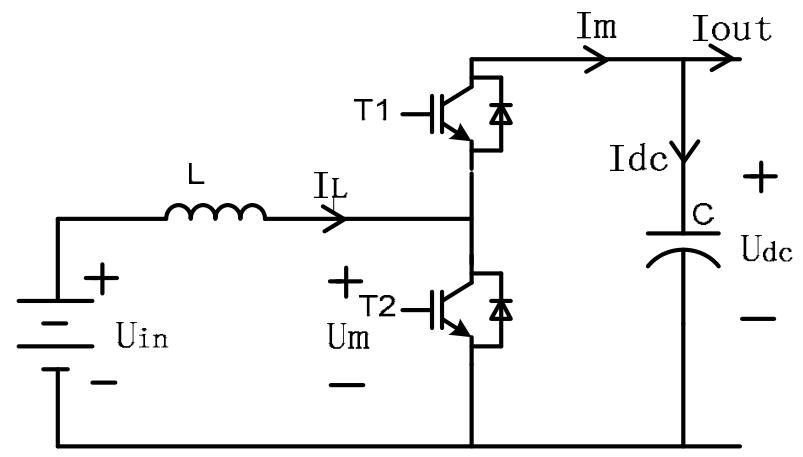

Fig 5.Bi-DC/DC converter

Control strategy of Bi-DC/DC converter as shown in Fig. 5 is very important to keep voltage of DC bus stable in islanded operation. The storages exchange power with others by the DC-capacitor: 


$$
C \frac{d U_{d c}}{d t}=I_{d c}
$$

where $C$ is the equivalent capacitor,

$U_{d c}$ is the voltage of DC bus,

$I_{d c}$ is the current applied to the DC-bus capacitor.

According to equation (2), $I_{L-r e f}$ is obtained by equation (3):

$$
I_{m-r e f}=P I\left(U_{d c-r e f}-U_{d c}\right)+I_{\text {out }}
$$

For inductor L, equation (4) describes the relationship between voltage and current:

$$
L \frac{d I_{L}}{d t}=U_{i n}-U_{m}
$$

where $L$ is the equivalent inductance,

$U_{i n}$ is the voltage of battery or super capacitor,

$U_{m}$ is the modulated voltage of chopper.

According to equation (4) and linear relationship between $I_{m-r e f}$ and $I_{L-r e f}, U_{m-r e f}$ is obtained by equation (5):

$$
U_{m-r e f}=U_{i n}+P I\left(I_{L-r e f}-I_{L}\right)
$$

The average modulation function of converter is obtained by equation (6):

$$
m=\frac{U_{m-r e f}}{U_{d c}}
$$

So we can get control strategy of Bi-DC/DC converter for voltage of DC bus from upper equations as shown in Fig. 6. In islanded operation storage system is used to not only keep voltage of DC bus stable but also absorb or release the power difference between renewable energy generations and loads with the control strategy ${ }^{[6,7]}$.

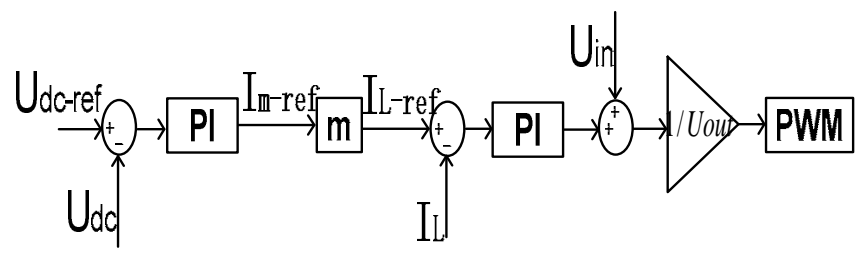

Fig 6. Block diagram of the controller for charging

In equation (3) $I_{m-r e f}$ is the sum current of renewable energy generations and storage system:

$$
I_{m-r e f}=I_{\text {wind }-m-r e f}+I_{s c-m-r e f}+I_{\text {storage-m-ref }}
$$

where $\quad I_{\text {storage-m-ref }}=I_{\text {batt-m-ref }}+I_{\text {sc-m-ref }}$

In Fig. 4 we can get equation (9) and (10):

$$
\begin{gathered}
I_{\text {batt-m-ref }}=K I_{\text {storage-m-ref }}(9) \\
I_{s c-m-r e f}=(1-K) I_{\text {storage-m-ref }}
\end{gathered}
$$

$\mathrm{K}$ is determined by rating and SOC of super-capacitor and batteries. Also the gain will affect voltage of DC bus in transient operation when DC loads change or power from wind turbine and photovoltaic panels is fluctuant rapidly. The super capacitors as fast-dynamic storage system must absorb or release power quickly. We can make $\mathrm{K}=0.1 \sim 0.3$ in transient operation.. After transition the strategy controls $\mathrm{K}=0.7 \sim 0.9$, because the batteries store more energy.

\section{SIMULATION AND EXPERIMENTAL RESULTS}

When there are some faults happened in utility grid, mircogrid will work in islanded operation. At the time, voltage of DC bus is not kept by inverter. Instead, the storage system and renewable energy generations will keep DC-bus voltage constant with control strategies. Fig. 7 shows that when $t=0.2 \mathrm{~s}$ microgrid system began to work in islanded operation, voltage of DC bus can be kept stable.

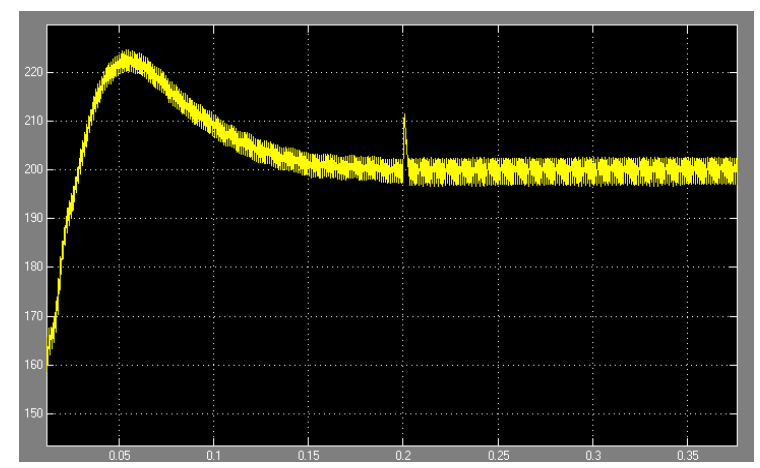

Fig 7.Voltage of DC bus when microgrid works from grid-connected to island

When DC loads change in islanded operation, the voltage of DC bus should be kept constant by storage system, and different K will lead different response speed. From Fig. 8 and Fig. 9, we can see when DC loads changed or power from wind turbine and photovoltaic panels was fluctuant rapidly, the super capacitors must be release or absorb more power.

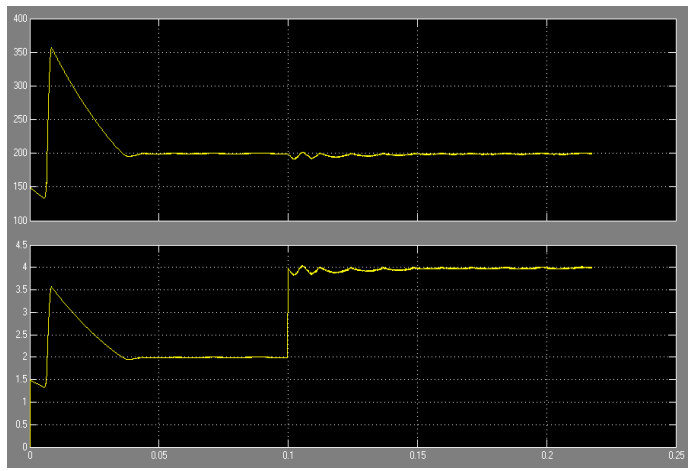

Fig 8.Voltage of DC bus (up) and current of load (down) when $\mathrm{K}=0.3$ 


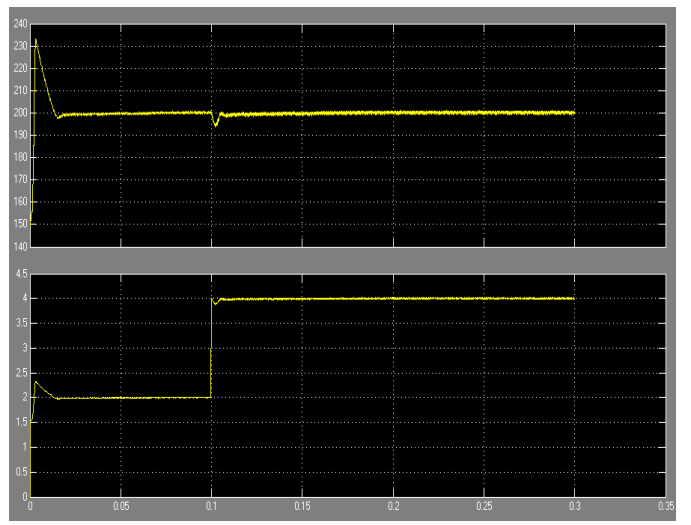

Fig 9.Voltage of DC bus (up) and current of load (down) when $\mathrm{K}=0.7$

In order to make the voltage of DC bus stable more quickly, the equivalent inductance $L$ can be changed smaller. In Fig $10 I_{L-r e f}$ is set to $10 \mathrm{~A}$ first, when $\mathrm{t}=1 \mathrm{~s} I_{L-r e f}$ is changed to $20 \mathrm{~A}$. And the equivalent inductance $\mathrm{L}$ is set $5 \mathrm{mH}$ in pink line and $1 \mathrm{mH}$ in yellow line.

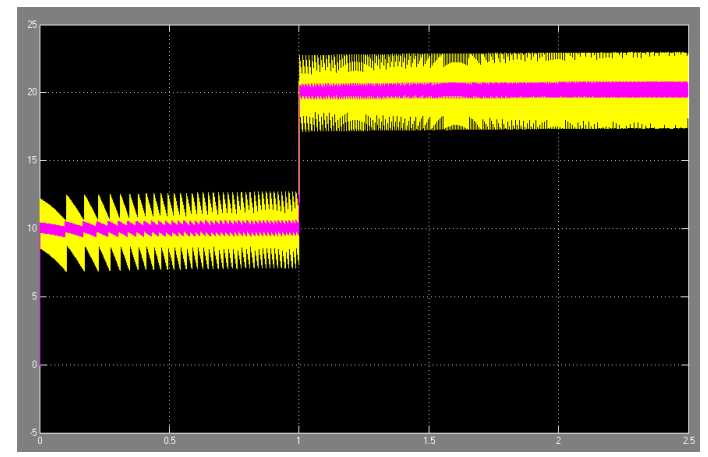

Fig 10a.Currents of inductance L

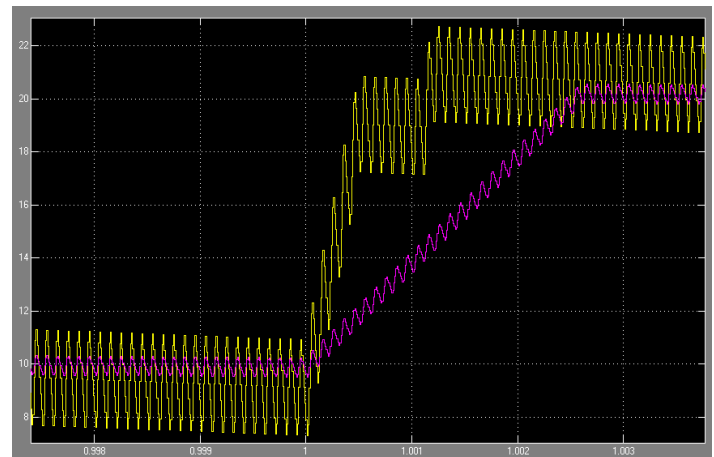

Fig 10b.Transient operation

\section{CONCLUSION}

This paper introduces the strategies of different converters in the hybrid DC and AC bus linked microgrid. Also strategies for grid-connected, islanded and transition operations are described in the paper. With these strategies, the power between microsources, storage systems, loads and utility grid could be kept balance. In island operation, the microsources and storage systems are used to keep the voltage of DC bus steady and the simulation results are described.

\section{ACKNOWLEDGMENT}

This paper and its related research are supported by grants from the Power Electronics Science and Education Development Program of Delta Environmental \& Educational Foundation.

\section{REFERENCES}

[1] Z. Tao, L. Peng, and B. Francois, "Power management strategies of a DC-coupled hybrid power system in a microgrid for decentralized generation," in Power Electronics and Applications, 2009. EPE '09. 13th European Conference on, 2009, pp. 1-10.

[2] J. Zhenhua and Y. Xunwei, "Hybrid DC- and AC-Linked Microgrids: Towards Integration of Distributed Energy Resources," in Energy 2030 Conference, 2008. IEEE, 2008, pp. 1-8.

[3] K. De Brabandere, B. Bolsens, J. Van den Keybus, A. Woyte, J. Driesen, R. Belmans, and K. U. Leuven, "A voltage and frequency droop control method for parallel inverters," in Power Electronics Specialists Conference, 2004. PESC 04. 2004 IEEE 35th Annual, 2004, pp. 2501-2507 Vol.4

[4] R. H. Lasseter, "MicroGrids," in Proc. IEEE Power Eng. Winter Meeting, New York, Jan. 2002.

[5] P. Piagi and R. H. Lasseter, “Autonomous control of microgrids,” in Proc. IEEE Power Eng. Soc. Meeting, Montreal, Canada, Jun. 2006. [Online]. Available: http://certs.lbl.gov/CERTS_P_DER.html.

[6] H. Nikkhajoei and R. H. Lasseter, "Distributed Generation Interface to the CERTS Microgrid," Power Delivery, IEEE Transactions on, vol. 24, pp. 1598-1608, 2009.

[7] G. Fang and M. R. Iravani, "A Control Strategy for a Distributed Generation Unit in Grid-Connected and Autonomous Modes of Operation," Power Delivery, IEEE Transactions on, vol. 23, pp. 850859, 2008.

[8] Haihua Zhou, Bhattacharya, "Composite energy storage system with flexible energy management capability for micro-grid applications”, Energy Conversion Congress and Exposition, 2010, pp. 2558-2563. 